\author{
EMILIA ŚMIECHOWSKA-PETROVSKIJ \\ Wydział Nauk Pedagogicznych \\ Uniwersytet Kardynała Stefana Wyszyńskiego \\ Warszawa
}

Forum Pedagogiczne 2016/1

Wpłynęło: 30.11 .2015

Zatwierdzono do druku: 3.03 .2016

\title{
NURTY BADAWCZE WE WSPÓŁCZESNYCH ZAGRANICZNYCH STUDIACH POŚWIĘCONYCH PROBLEMATYCE NIEPEŁNOSPRAWNOŚCI WZROKOWEJ
}

Streszczenie: W artykule zaprezentowano współczesne zagraniczne kierunki badań naukowych oraz prac rozwojowych w obszarze edukacji i rehabilitacji osób z dysfunkcją wzroku. Zidentyfikowano następujące główne nurty badawczo-wdrożeniowe: edukacja brajlowska, tyflograficzna i technologie wspomagające - strategie na rzecz nauczania przedmiotów ścisłych; współczesna orientacja przestrzenna osób niewidomych i słabowidzących, uwarunkowania oraz jej efektywność jako predyktor zatrudnienia; aktywność fizyczna osób z dysfunkcją wzroku - stan oraz wytyczne edukacyjno-rehabilitacyjne. Podsumowaniem analiz są konkluzje odnoszące się do zagadnień metodologicznych oraz prakseologicznych.

Słowa kluczowe: osoby niewidome, osoby słabowidzące, system L. Braille’a, orientacja przestrzenna, technologie wspomagające

\section{Wprowadzenie}

Przedmiotem opracowania jest ukazanie nurtów badawczych we współczesnych zagranicznych studiach poświęconych problematyce niepełnosprawności wzrokowej. Podjęcie takich rozważań jest nawiązaniem do prac na temat tendencji w tyflopedagogice w Polsce (Kuczyńska-Kwapisz 1996, 2004) i na świecie (Łobacz 2004, 2006) - stanowi ich kontynuację.

Zidentyfikowanie współczesnych zagranicznych kierunków badań naukowych oraz prac rozwojowych w obszarze funkcjonowania, edukacji i rehabilitacji osób z dysfunkcją wzroku, jako cel artykułu, motywowane jest następującymi przesłankami. Analiza dyskursu naukowego umożliwi wyznaczenie punktów odniesień dla badań krajowych, co pozwoli zainteresowanym na porównanie potrzeb poznawczych i praktycznych w perspektywie zagranicznej i lokalnej oraz na ustalenie stopnia zróżnicowania lub korespondowania problematyki badawczej. Wyłonienie zagranicznych studiów poświęconych niepełnosprawności wzrokowej może być również dla badaczy krajowych impulsem do określenia, jakie strategie 
prowadzenia badań dominują w projektach zagranicznych (problemy badawcze i procedury ich rozwiązywania mogą stać się swoistym filtrem analitycznym dla eksploracji krajowych).

Analizie poddano artykuły publikowane w latach 2014-2015 w czasopismach naukowych „Journal of Visual Impairment and Blindness” i „British Journal of Visual Impairment" oraz referaty wygłoszone podczas 14th Biennial Conference of the International Association of Special Education (IASE) „New dimensions toward education, advocacy and collaboration for individuals with special needs" (2015 r.). Wybór źródeł podyktowany jest ich specyfiką i zasięgiem oddziaływania. "Journal of Visual Impairment and Blindness" (wydawca: American Foundation for the Blind) i „British Journal of Visual Impairment” (wydawca: SAGE Publishing) są wiodącymi, recenzowanymi czasopismami naukowymi o zasięgu światowym, poświęconymi problematyce niepełnosprawności związanej ze wzrokiem. Autorzy z całego świata publikują tam wyniki badań, doniesienia z własnej praktyki, a także analizy kluczowych tematów związanych z niepełnosprawnością wzrokową, komentarze, recenzje. Natomiast International Association of Special Education jest światową organizacją, powołaną w 1985 roku, aby wspierać osoby ze specjalnymi potrzebami edukacyjnymi w zakresie podnoszenia jakości życia i budowania infrastruktury edukacyjno-rehabilitacyjnej w różnych krajach świata. IASE zrzesza członków z 48 krajów. Co dwa lata organizuje międzynarodową konferencję, stającą się forum prezentacji wyników badań i dobrych praktyk w zakresie wsparcia osób z niepełnosprawnościami w ujęciu globalnym. Ostatnia konferencja miała miejsce w 2015 roku w Polsce ${ }^{1}$ - wzięło w niej udział 290 przedstawicieli 31 krajów, w tym rozwijających się, dlatego to źródło doniesień naukowych zostało włączone do zbioru analizowanych treści.

Analizie poddano łącznie 170 artykułów naukowych (wszystkie opublikowane teksty naukowe w dwóch rocznikach czasopism) oraz pięć referatów konferencyjnych (wyłącznie te wystąpienia, które poświęcone były niepełnosprawności narządu wzroku). Na podstawie słów kluczowych wyodrębniono najczęściej poruszane wątki tematyczne.

Chociaż obrana strategia rekonstrukcji współczesnych nurtów badawczych w zagranicznych studiach poświęconych niepełnosprawności wzrokowej ma swoje ograniczenia, bo pozwala jedynie na uchwycenie wybranego wycinka rzeczywistości, który reprezentuje jego właściwości w danym czasie, to jej efekt może okazać się produktywny zarówno dla naukowców, jak i praktyków z obszaru pedagogiki osób z niepełnosprawnością wzrokową.

${ }^{1}$ Gospodarzem konferencji zorganizowanej 21-25 czerwca 2015 r. była Dolnośląska Szkoła Wyższa we Wrocławiu. 


\section{Problematyka współczesnych zagranicznych studiów poświęconych niepełnosprawności wzrokowej}

Problematyka analizowanych opracowań naukowych jest zróżnicowana. Dotyczy kluczowych aspektów funkcjonowania oraz szeroko rozumianej edukacji i rehabilitacji osób niewidomych i słabowidzących, co obrazuje rysunek.

Rysunek. Obszary problemowe w zagranicznych studiach nad niepełnosprawnością wzrokową (opracowanie własne)

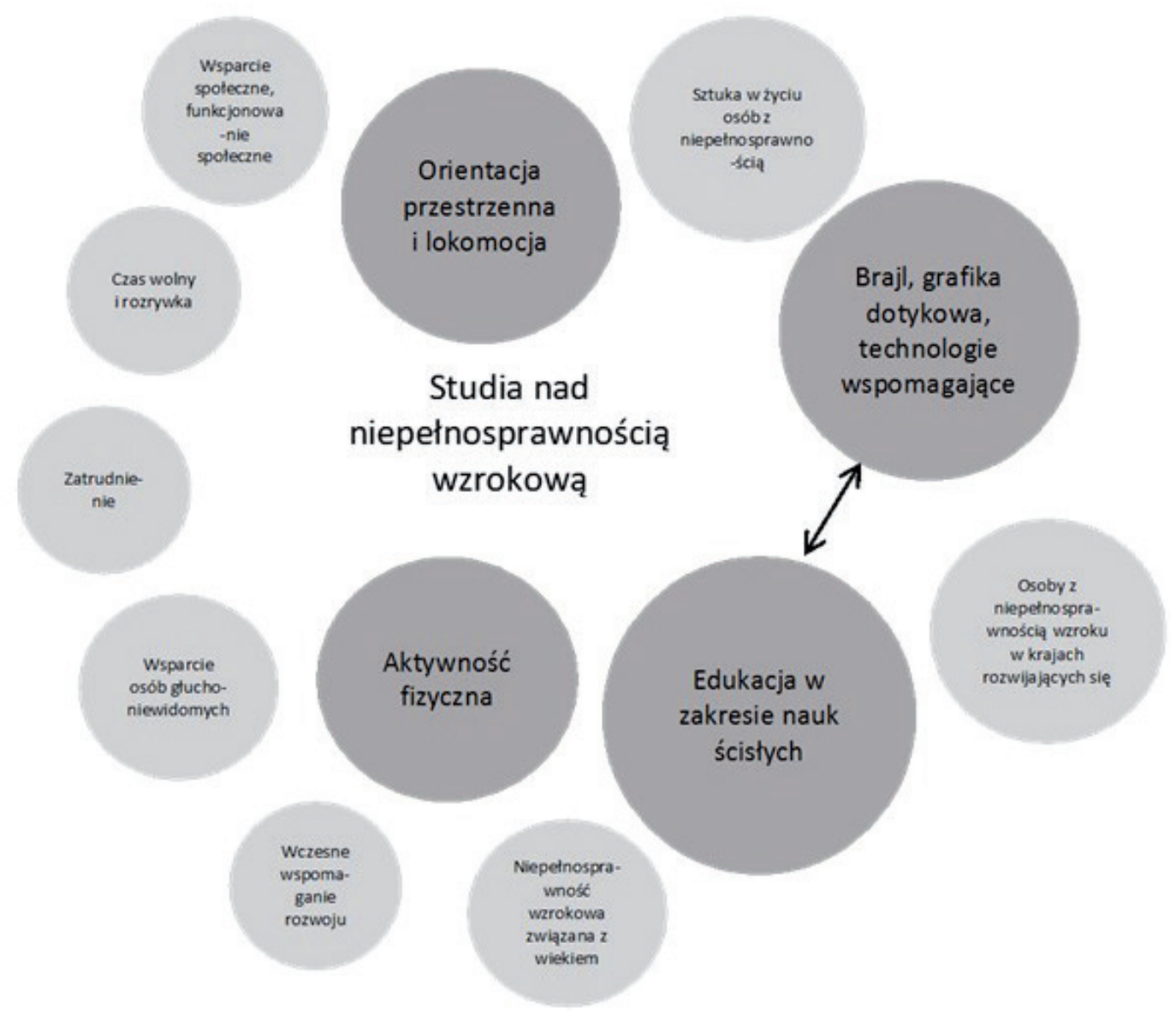

Ze względu na częstość występowania zagadnień w publikacjach omówione zostaną następujące główne obszary zainteresowań badawczych:

- Zagadnienia dotyczące technik brajlowskich, grafiki dotykowej, technologii wspomagających; w tym - w kontekście edukacji osób z dysfunkcją wzroku w zakresie nauk ścisłych.

2 Im większe pola oraz stopień ich wyszarzenia, tym większa reprezentacja tematyki w analizowanym korpusie tekstów. Strzałka obrazuje dwustronne zależności pomiędzy obszarami. 
- Orientacja w przestrzeni i samodzielne poruszanie się osób z dysfunkcją wzroku.

- Aktywność fizyczna osób z dysfunkcją wzroku.

Techniki brajlowskie, grafika dotykowa, technologie wspomagające. Ich wykorzystanie w edukacji osób z dysfunkcją wzroku w zakresie nauk ścisłych

Techniki brajlowskie, grafika dotykowa i technologie wspomagające potraktowano jako narzędzia komunikacji różnych treści osobom z dysfunkcją wzroku, dlatego zaprezentowano je łącznie. Ich eksploracje, oprócz zupełnie rozdzielnych analiz poświęconych zagadnieniom szczegółowym, często współwystępują, a łącznikiem staje się ich wykorzystanie w edukacji niewidomych i słabowidzących w zakresie przedmiotów ścisłych.

\section{Edukacja brajlowska}

Wątki tematyczne współczesnej edukacji brajlowskiej obejmują:

- edukację prebrajlowską (przygotowanie niewidzących dzieci do nauki systemu brajla);

- wczesną edukację brajlowską (naukę czytania i pisania - system L. Braille’a jako medium opanowania podstawowych technik szkolnych);

- edukację brajlowską osób tracących wzrok (przechodzących z technik wzrokowych na techniki dotykowe);

- edukację brajlowską osób $\mathrm{z}$ dysfunkcją wzroku z dodatkowymi niepełnosprawnościami;

- edukację brajlowską osób dorosłych i starszych - tracących wzrok i ociemniałych;

- edukację brajlowską osób widzących w celu komunikacji z osobami niewidzącymi (nauczycieli, terapeutów, rodziców, studentów przygotowujących się do wykonywania zawodu nauczyciela) (Śmiechowska-Petrovskij 2016).

$\mathrm{W}$ ostatnich latach badania w tym obszarze ukierunkowane były na testowanie oraz weryfikowanie efektywności strategii i instrukcji:

- nauczania brajla uczniów z dysfunkcją wzroku, tracących wzrok i przechodzących ze zwykłego druku na brajla;

- edukacji brajlowskiej dzieci z niepełnosprawnością wzrokową sprzężoną (niepełnosprawność wzrokowa oraz autyzm i/lub niepełnosprawność intelektualna);

- nauczania brajla osób tracących wzrok i ociemniałych w wieku dorosłym.

Metodą podlegającą testowaniu w edukacji brajlowskiej uczniów tracących wzrok jest procedura time delay (Browder i in. 2009; Hooper i in. 2014; Ivy, Hooper 2015). Osoby przechodzące ze zwykłego druku na brajla muszą nauczyć się nowego systemu zapisu w najefektywniejszy sposób, a czas przeznaczony na naukę powinny 
spożytkować możliwie najwydajniej. Oprócz ćwiczeń rozwijających percepcję dotykową oraz rozpoznawanie i identyfikowanie liter brajlowskich, potrzebne jest opanowanie symboli z notacji matematycznej, fizycznej czy chemicznej, aby w pełni wykorzystywać system brajlowski w edukacji i życiu codziennym.

Procedura time delay składa się z dwóch faz: fazy instrukcji, w której znak brajlowski oraz interwencja (podpowiedź), czyli głośne odczytanie znaku, następują natychmiast po sobie, oraz fazy odroczenia, w której pojawia się 5-sekundowa przerwa pomiędzy prezentacją znaku brajlowskiego a podpowiedzią. W tym drugim przypadku uczeń ma czas na samodzielne rozpoznanie znaku. Nauka przebiega podczas kilkunastu sesji, podczas których wybrane grupy znaków prezentowane są w kilku próbach, składających się z fazy instrukcji i odroczenia (Cooper i in. 2007; Ivy, Hatton 2015; Ivy, Hooper 2015). Metoda ta okazała się skuteczna w uczeniu brajla młodzieży, która miała już za sobą wstępną naukę rozpoznawania liter brajlowskich (badani w ciągu miesiąca nauczyli się od 28 do 40 symboli). Badacze podkreślają, że time delay może być dobrym uzupełnieniem tradycyjnych strategii edukacji brajlowskiej. Wymaga jednak wciąż empirycznych eksploracji. Oceniając wyniki uczniów, nie analizowano takich predyktorów osiągnięć, jak zróżnicowanie ze względu na wcześniejszą stymulację dotykową oraz trening w zakresie umiejętności powiązanych z brajlem. Ustalenia wymaga również liczba prób i sesji dla efektywnego nauczania danej serii znaków (Śmiechowska-Petrovskij 2016).

Inną testowaną współcześnie metodą nauki systemu brajlowskiego jest Individualized Meaning-centered Approach to Braille Literacy Education (I-M-ABLE) (Wormslay 2011). Zakłada ona tworzenie środowiska ubrajlowionego (etykiety brajlowskie) i zindywidualizowanych materiałów czytelniczych oraz skupienie się w początkowym etapie nauki na stworzeniu niewielkiego słownika użytkowników, składającego się z wyrazów znaczących dla ucznia, które sam wybrał. Metoda ta jest szczególnie przydatna $\mathrm{w}$ pracy $\mathrm{z}$ dziećmi, u których tradycyjne podejście do nauki brajla nie przynosi satysfakcjonujących efektów (wysiłek rozpoznawania znaków brajlowskich uniemożliwia zrozumienie sensu logicznego odczytywanych tekstów). Uczniowie tworzą w brajlu swoje historyjki i je odczytują. Nauczyciel dodaje słowa wypełniacze, potrzebne, żeby nadać sensowne brzmienie opowieści. Tak zaplanowana nauka jest angażująca i motywująca. Metoda sprawdza się w szczególności w pracy z uczniami z niepełnosprawnością intelektualną, a także zaburzeniami ze spektrum autyzmu, również z tymi, którzy przechodzą $\mathrm{z}$ druku zwykłego na system brajlowski (Campbell 2011; D’Aurizio 2011; McMillan 2015). Potrzebne jest jednak sprawdzenie jej możliwości i efektywności w nauczania brajla bez skrótów brajlowskich (uncontracted braille), bo brakuje empirycznych weryfikacji metody w użyciu brajla integralnego - notacji podstawowej m.in. w języku polskim (Śmiechowska-Petrovskij 2016).

Testowane jest również inne podejście do nauki brajla osób dorosłych, $\mathrm{z}$ wykorzystaniem warsztatów grupowych, których elementami strukturalnymi są dyskusja i dzielenie się doświadczeniami (Farrow 2015). 
W badaniach sprawdzane są także wzorce rozpoznawania znaków brajlowskich (Graven 2015) oraz predyktory efektywności czytania brajlem (takie jak płeć, moment utraty widzenia oraz etap edukacyjny). Wykazano, że kobiety, ociemniali i uczniowie szkoły podstawowej popełniają więcej błędów w zapisie brajlowskim (Koutsoklenis, Papadopoulos 2015). Z kolei w innych badaniach stwierdzono zależność pomiędzy okresem funkcjonowania bez wzroku a płynnością czytania (Oshima i in. 2014).

\section{Edukacja tyflograficzna}

Aktualne poszukiwania naukowe, dotyczące wykorzystywania grafiki dotykowej w pracy z osobami niewidomymi, ukierunkowane są na określenie:

- stopnia czytelności grafik przygotowanych w różnych technikach i zgodnie z różnymi zasadami redagowania, a także czynników mających znaczenie dla preferencji określonych technik przez użytkowników i komunikatywności grafik;

- umiejętności i strategii zapoznawania się z grafikami wypukłymi;

- możliwości wykorzystania drukarek 3D w tworzeniu tyflografik;

- diagnozowania postaw wobec grafik dotykowych uczestników procesów dydaktycznych: nauczycieli, uczniów, rodziców.

W serii badań (Zebehazy, Wilton 2014a, 2014b, 2014c) analizowano stosunek uczniów do wypukłych reprezentacji graficznych stosowanych na lekcjach oraz perspektywę nauczycieli pracujących z uczniami z dysfunkcją wzroku w odniesieniu do użytkowania grafiki dotykowej - ich doświadczenia dydaktyczne z użyciem tyflografik.

Badani uczniowie pozytywnie wyrażali się o tyflografice i sygnalizowali potrzebę większego dostępu do ilustracji wypukłych, choć tylko jedna trzecia z nich deklarowała, że grafiki pomagają zrozumieć wprowadzane pojęcia lepiej niż sam tekst objaśniający, a ponad połowa przyznała, że nie nadąża za tokiem lekcyjnym, korzystając z reprezentacji graficznych. Uczniowie w większości preferowali współwystępowanie komentarza słownego i grafiki dotykowej - uznawali taką strategię za bardzo pomocną (podobnie jak pracujący z nimi nauczyciele), jednak największą korzyść poznawczą zyskiwali przez zapoznawanie się z modelami trójwymiarowymi obiektów (lub obiektami naturalnymi). Tworzenie własnych reprezentacji graficznych nie było przez nich wykorzystywane jako sposób utrwalania informacji - również nauczyciele najczęściej nie uczą niewidzących tworzenia własnych tyflograficznych reprezentacji.

Wyzwaniem w skutecznym posługiwaniu się grafikami dotykowymi przez uczniów okazały się zbyt małe odległości pomiędzy elementami wypukłymi, wysoki poziom skomplikowania grafik (dużo elementów, szczegółów, np. na wypukłych mapach), niewystarczająco zróżnicowane taktylnie płaszczyzny, reprezentacje obiektów trójwymiarowych w dwuwymiarze, niewystarczająca obudowa słowna 
grafik (podpisy, legendy, komentarze objaśniające). Zwiększenie skuteczności wykorzystania tyflografik badani wiązali z dodatkowymi tekstami objaśniającymi oraz możliwością wcześniejszego zapoznania się z grafikami - zarówno razem z nauczycielem, jak i samodzielnie. W zakresie walorów fizykalnych ilustracji wypukłych wskazywali na potrzebę lepszych tekstur (wyraźniejszych różnic dotykowych pomiędzy płaszczyznami), większych odległości między elementami rysunku i mniejszego poziomu skomplikowania treściowego rysunków (pominięcia szczegółów).

Nauczyciele uczniów z dysfunkcją wzroku bardziej optymistycznie podchodzili do potencjału grafiki dotykowej w procesie kształtowania pojęć niż sami uczniowie, jednak tylko co piąty badany był zdania, że uczniowie są w stanie samodzielnie zapoznawać się z grafiką i korzystać z informacji w niej zawartych. Ponad 60\% nauczycieli przyznało, że ma niewystarczająco dużo czasu, aby nauczyć korzystania $\mathrm{z}$ grafiki dotykowej.

Penny Rosenblum i Tina Herzberg (2015) wskazują, na podstawie badań poświęconych wykorzystywaniu technik brajlowskich i grafiki dotykowej w nauce przedmiotów ścisłych przez dzieci niewidome, że kluczowe znaczenie w skutecznej komunikacji tyflograficznej ma klarowność, jasność przekazywanych informacji oraz właściwe zróżnicowanie taktylne obiektów wypukłych. Zwracają także uwagę na konsekwencje braku adekwatnych materiałów doświadczanego przez część użytkowników - wyłącza to tę grupę z głównego nurtu działań lekcyjnych, powodując kończenie zadania $\mathrm{z}$ dużym opóźnieniem lub niekończenie go wcale.

\section{Technologie wspomagające}

Współczesne teoretyczno-empiryczne poszukiwania dotyczące technologii wspomagających dla osób niewidomych i słabowidzących odnoszą się do takich zagadnień, jak:

- projektowanie nowych urządzeń i systemów wspomagających uwzględniających potrzeby, możliwości i preferencje osób niepełnosprawnych wzrokowo ewaluacja ich użyteczności i efektywności w zakresie wykonywania zadań;

- proces nabywania umiejętności posługiwania się technologiami wspomagającymi przez osoby niewidome i słabowidzące (umiejscowienie treści dotyczących wspomagających technologii informacyjno-komunikacyjnych w programach nauczania, dostęp do sprzętu i oprogramowania przez osoby z dysfunkcją wzroku) oraz wykorzystywanie technologii wspomagających w obrębie różnych przedmiotów szkolnych, a także w życiu codziennym i zawodowym;

- kompetencje nauczycieli uczniów z dysfunkcją wzroku w zakresie doboru sprzętu i oprogramowania oraz metodyki nauczania i strategii lekcyjnych wykorzystujących technologie wspomagające; 
- preferencje użytkowników z dysfunkcją wzroku co do wyboru i wykorzystania wspomagającego sprzętu i oprogramowania, rola czynników społecznych i cech osobniczych niewidomych i słabowidzących w procesie wyboru i użytkowania technologii.

Eksplorowanie kompetencji nauczycieli uczniów z dysfunkcją wzroku w zakresie korzystania $\mathrm{z}$ technologii wspomagających prowadzi do pesymistycznych wniosków - potwierdza ich niską wiedzę na temat dostępnych narzędzi informacyjno-komunikacyjnych dla uczniów niewidomych i słabowidzących oraz niewystarczające umiejętności w zakresie nauczania technologii (Siu, Morash 2014, por. także: Zhou i in. 2011; Smith i in. 2009).

Aktualnie najszerzej jednak analizowane są możliwości wykorzystania nowych technologii informacyjno-komunikacyjnych w zakresie nauczania przedmiotów ścisłych, co zostanie omówione w dalszej części artykułu.

Techniki brajlowskie, grafika dotykowa, pomoce dotykowe oraz technologie wspomagające w edukacji osób z dysfunkcją wzroku w zakresie nauk ścisłych

Uczniowie z dysfunkcją wzroku uzyskują niższe niż osoby bez dysfunkcji wyniki nauczania z przedmiotów ścisłych, zwłaszcza z matematyki (Giesen i in. 2012), dlatego we współczesnych projektach badawczych i aplikacyjnych edukacja uczniów z dysfunkcją wzroku w tym zakresie (nauczania matematyki, chemii, fizyki, biologii, informatyki, geografii) zajmuje szczególne miejsce. Dostępność nowych narzędzi wspomagających i formatów pomocy dydaktyczno-rehabilitacyjnych (grafiki dotykowe, programy komputerowe oraz aplikacje na tablety i smartfony, elektroniczne urządzenia do odczytu grafiki, elektroniczne maszyny brajlowskie i inne) jest postrzegana jako potencjał koncepcyjno-technologiczny, który - dobrze wykorzystany - może mieć duże znaczenie dla efektywności edukacji niewidomych i słabowidzących w zakresie nauk ścisłych. Ale jednocześnie coraz częściej planuje się przedsięwzięcia interdyscyplinarne i wykorzystuje potencjał nie tylko specjalistów z zakresu edukacji i rehabilitacji osób z dysfunkcją wzroku, ale również reprezentantów innych dziedzin nauki.

Dla podnoszenia efektywności edukacji w zakresie nauk ścisłych ważna jest dostępność materiałów dydaktycznych oraz ich jakość. Z doniesień badawczych wynika, że uczniowie nie zawsze otrzymują podstawowe pomoce dotykowe. Tymczasem wśród niewidzących uczniów i studentów panuje zgoda, że materiały w brajlu papierowym są niezbędne do nauki matematyki i przedmiotów ścisłych oraz języków obcych, niezależnie od poziomu edukacyjnego i nastawienia do brajla (D’Andrea 2012). W ogóle grafika dotykowa i techniki brajlowskie są najczęściej wykorzystywane podczas edukacji matematycznej (91\%) i innych nauk ścisłych (86\%), w znacznie mniejszym stopniu natomiast w nauczaniu przedmiotów humanistycznych (Zebehazy, Wilton 2014c). W obszarze wspierania uczniów w opanowaniu 
notacji matematycznej testowana jest wspomniana wcześniej procedura time delay (Ivy, Hooper 2015).

W stosunku do jakości materiałów brajlowsko-tyflograficznych formułowane są postulaty wynikające z prowadzonych badań i płynących z nich konkluzji. $\mathrm{W}$ procesie przygotowania grafik dotykowych istotne jest, aby rysunek komunikował określony koncept lub informację, a nie służył do odwzorowania wizualnej reprezentacji w formie dotykowej. Niezbędne jest także przekazywanie uczniom dodatkowych instrukcji, jak na ilustracji dotykowej znajdować informacje oraz jak dokonywać pomiarów i analiz danych, a prototypy tyflografik powinny być konsultowane $\mathrm{z}$ odbiorcami (Rosenblum, Herzberg 2015). W innych badaniach wskazywano na liczne błędy (literowe, w zakresie notacji matematycznej oraz „edycji” brajlowskiej) w grafikach dotykowych (Herzberg, Rosenblum 2014).

Wykorzystanie technologii informacyjno-komunikacyjnych, w tym wspomagających, na lekcjach nauk ścisłych to kolejny obszar analiz. Podstawowe pytania są następujące: jakie technologie wspomagające wykorzystuje się w nauce matematyki? Jak są one implementowane? W jaki sposób różnicują efektywność edukacji matematycznej uczniów? (DePountis i in. 2015). Badacze wskazali 13 narzędzi o wysokim poziomie zaawansowania technicznego, z których najczęściej korzystają nauczyciele i które mają znaczenie dla opanowania przez uczniów z dysfunkcją wzroku treści matematycznych: komputer, skaner lub czytnik, notatnik brajlowski, Math Flash (matematyczne gry multimedialne), udźwiękowiony kalkulator, Excel, udźwiękowiony naukowy kalkulator, dyktafon, Duxbury Braille Translator (DBT), program do rozpoznawania druku (OCR), notebook, Graph-It (aplikacja służąca do nauki algebry), Accessible Graphing Calculator (program komputerowy do zapoznawania się $\mathrm{z}$ treściami matematycznymi $\mathrm{w}$ formie graficznej za pomocą słuchu i/lub dotyku z modułem liczącym). Wykorzystywane są one przede wszystkim w zakresie treści algebraicznych. Badacze zauważają jednak, że mimo technologicznego skoku narzędzia o niskim stopniu zaawansowania wciąż cieszą się największym zainteresowaniem.

W innych badaniach sprawdzano możliwości wykorzystania tabletów do nauki matematyki przez osoby z dysfunkcją wzroku. Testowano aplikację na iPada, oferującą interaktywne lekcje algebry z materiałami tyflograficznymi oraz audiodeskrypcją obiektów wizualnych (Beal, Rosenblum 2015). Ten kierunek prac rozwojowych jest również eksplorowany na gruncie krajowym. W Polsce powstała interaktywna platforma PlatMat, wspierająca naukę matematyki i przeznaczona dla uczniów z dysfunkcją wzroku (por. sprawozdanie z konferencji: PlatMat: Narzędzia informatyczne dla właczajacej edukacji matematycznej uczniów z dysfunkcjami narządu wzroku, s. 389).

Swoistą tendencją w zakresie wsparcia uczniów w nauce przedmiotów ścisłych jest organizowanie obozów naukowych dla niewidomych i słabowidzących. Są to na ogół projekty wdrożeniowo-badawcze, w ramach których oprócz realizowania celów edukacyjnych prowadzone są także badania poświęcone kompetencjom 
nauczycieli, efektywności stosowanych metod, postępom uczniów oraz postawom nauczycieli i asystentów w odniesieniu do edukacji (Chiu 2015; Nepomuceno i in. 2016; Reynaga-Peña 2015a, 2015b; Wild i in. 2014).

Także w tym obszarze dostrzec można tendencje do interdyscyplinarnej współpracy. W meksykańskim projekcie (Reynaga-Peña 2015a, 2015b) stworzono multidyscyplinarny zespół (w jego skład wchodzili naukowcy - biolodzy, nauczyciele szkół specjalnych dla dzieci niewidomych i słabowidzących, plastycy), a następnie zaprojektowano i skonstruowano trójwymiarowe modele obrazujące treści biologiczne, również z modułami dźwiękowymi. Wypracowane pomoce zostały wykorzystane podczas obozu naukowego dla dzieci niewidomych i słabowidzących. Projekt obejmował szkolenie nauczycieli, badanie dostępności taktylnej i wzrokowej przygotowanych modeli przez niewidomych i słabowidzących oraz strategii łączenia pracy na bazie tych pomocy poglądowych oraz innych praktycznych i polisensorycznych aktywności. Społeczne oddziaływanie projektu okazało się bardzo duże po zakończeniu obozu zaczęto szkolić nauczycieli ze zwykłych szkół, zachęcając ich do włączania modeli i wypracowanych strategii dydaktycznych do programów nauczania w szkołach ogólnodostępnych. Stworzono wypożyczalnię modeli oraz zaczęto udostępniać je zarówno w szkołach specjalnych, jak też inkluzyjnych oraz zwykłych, do których nie uczęszczali uczniowie niepełnosprawni wzrokowo.

\section{Orientacja w przestrzeni osób z dysfunkcją wzroku}

Współcześnie wskazuje się na cztery typy systemów poruszania się dla osób doświadczających głębokiej dysfunkcji wzroku:

- z widzącym przewodnikiem;

- z wykorzystaniem białej laski;

- z użyciem psa przewodnika;

- z wykorzystaniem elektronicznych narzędzi wspomagających mobilność ${ }^{3}$ (Electronic Travel Aids - ETA) (Smith, Penrod 2010).

Badania dotyczące orientacji przestrzennej i lokomocji skupiają się przede wszystkim na technikach i narzędziach, które umożliwiają niezależne i samodzielne podróżowanie, oraz na programach rehabilitacyjnych. Dae S. Kim i Robert W. Emerson (2014) analizowali skuteczność technik poruszania się z białą laską w kontekście wykrywania przeszkód, Athanasios Koutsoklenis i Konstantinos Papadopoulos (2015) sprawdzali zaś, które wskazówki dotykowe i w jakim zakresie są istotne dla osób niewidzących podczas poruszania się z białą laską w przestrzeni otwartej.

Dla programów nauczania w zakresie orientacji przestrzennej i bezpiecznego samodzielnego poruszania się duże znaczenie mają obecnie doniesienia badawcze odnoszące się do potencjału nowych technologii wspomagających. W literaturze

${ }^{3}$ ETA dzieli się na dwie grupy: do samodzielnego stosowania oraz jako uzupełnienie innych narzędzi i technik. 
wyróżnia się elektroniczne narzędzia wspomagające mobilność (ETA), które dostarczają informacji o obiektach na szlaku komunikacyjnym poprzez emitowanie fal dźwiękowych i sygnalizowanie przeszkód, np. wibracją w rękojeści białej laski, oraz elektroniczne narzędzia nawigacyjne (Electronic Orientation Aids - EOA), które służą do orientacji, nie zaś do wykrywania przeszkód. Znaczenie tych systemów w orientacji i mobilności osób $\mathrm{z}$ dysfunkcją wzroku jest słabo rozpoznane ze względu na koszt urządzeń, wymagania w zakresie treningu, brak specjalistów i wysoką efektywność innych systemów (w związku z tym liczba użytkowników i specjalistów jest ograniczona).

We współczesnych badaniach dotyczących orientacji przestrzennej i mobilności osób z niepełnosprawnością wzroku ważne miejsce zajmują analizy czynników psychospołecznych, istotnych dla podejmowanych aktywności. Problemy badawcze dotyczą m.in. tego, jakie są zależności pomiędzy osobistym stosunkiem do utraty widzenia, samooceną, poczuciem skuteczności a sukcesem w zakresie orientacji przestrzennej i bezpiecznego, samodzielnego poruszania się (samodzielnego i niezależnego podróżowania). Badane są na przykład czynniki społeczne, istotne dla osób niewidzących z punktu widzenia wybieranych strategii poruszania się. Główną troską niewidzących jest postrzeganie ich (przez siebie samych i innych) jako osoby „normalne”, dlatego preferowane techniki będą odpowiadały na tę potrzebę. Jednak kategoria normalności jest subiektywna, a także podlega rekonstrukcjom. Jeśli normalność jest postrzegana jako bycie taką osobą jak widzący, to skutkuje to odrzucaniem technik kojarzonych z niewidzeniem, ale gdy postrzegana jest jako sprawność i autonomia, to prowokuje do wykorzystywania wszelkich dostępnych technik i narzędzi, aby osiągnąć maksymalny poziom sprawczości i niezależności (Ball, Nicole 2015).

Eksplorowanie subiektywnych doświadczeń i perspektyw osób niewidomych i słabowidzących oraz uwzględnianie ich w trakcie doskonalenia programów rehabilitacyjnych z zakresu orientacji przestrzennej i lokomocji może przełożyć się na wyższą sprawność osób z dysfunkcją wzroku, co jest kluczowe dla ich sukcesu życiowego. Umiejętności w zakresie orientacji przestrzennej analizowane są jako predyktory zatrudnienia młodych ludzi z dysfunkcją wzroku. Osoby dobrze zrehabilitowane w zakresie orientacji (swobodnie poruszające się, korzystające z komunikacji miejskiej oraz międzynarodowej) są zatrudniane częściej niż osoby bez tych umiejętności (Lahav i in. 2015).

\section{Aktywność fizyczna}

Aktywność fizyczna osób z dysfunkcją wzroku jako przedmiot badań ma skromne odzwierciedlenie w literaturze naukowej, ale obecnie można odnotować większe zainteresowanie tą tematyką.

Ograniczony dostęp do informacji wizualnych lub jego brak powoduje, że osoby z dysfunkcją wzroku mają utrudnioną możliwość nabywania i rozwijania 
umiejętności wykonywania czynności motorycznych. Ponadto w przypadku niektórych schorzeń istnieją przeciwwskazania medyczne do pewnych typów aktywności fizycznej. Wyniki poszukiwań badawczych obrazują niższy poziom aktywności fizycznej osób z dysfunkcją wzroku w porównaniu z populacją ogólną oraz zwiększoną częstość występowania chorób cywilizacyjnych u osób niewidomych, a także wyższe ryzyko nadwagi i otyłości (por. przegląd badań: Augestad, Jiang 2015; Rosołek, Gawlik 2013). Badania pokazują także, że stopień dysfunkcji wzroku nie różnicuje w sposób istotny poziomu aktywności motorycznej, ale determinuje typy wybieranych ćwiczeń (Holbrook i in. 2009; Lieberman, MacVicar 2003; Sadowska, Krzepota 2015).

Współczesne badania naukowe ukierunkowane są na dalsze eksplorowanie stanu aktywności fizycznej osób niewidzących i słabowidzących, ale także na możliwości transferowania czynności motorycznych osób z dysfunkcją wzroku z okoliczności instytucjonalnych (szkoła, ośrodek rehabilitacyjny), w których są dyrektywnie inicjowane i praktykowane, na okoliczności pozainstytucjonalne (domowe, czas wolny), w których są podejmowane spontanicznie i wewnątrzsterownie (prowadzone są analizy poświęcone uwarunkowaniom tego procesu).

Badania Doroty Sadowskiej i Justyny Krzepoty ${ }^{4}$ (2015) (grupa osób dorosłych) oraz Justina A. Haegele’a i Davida L. Porretty (2015) (grupa uczniów szkolnych) potwierdzają, że osoby niewidome prezentują aktywność fizyczną o mniejszej częstotliwości i intensywności niż widzące.

Zmiana częstotliwości, intensywności i wzorców aktywności fizycznej uczniów z dysfunkcją wzroku związana jest z warunkami nabywania umiejętności fizycznych, które w głównej mierze odbywają się w okolicznościach instytucjonalnych. Badania pokazują, że uczniowie niewidzący i słabowidzący mają trudności w transferowaniu umiejętności wyuczonych w szkole na okoliczności pozaszkolne (Kriemler i in. 2011) i dlatego testowane i promowane są programy umożliwiające nabycie przez nich wiedzy proceduralnej i sprawności w zakresie jej zastosowania w innych sytuacjach (Haegele 2015). Wdraża się również projekty ukierunkowane na dynamizowanie współpracy pomiędzy nauczycielami wychowania fizycznego oraz innych przedmiotów a instruktorami orientacji przestrzennej w celu wsparcia uczniów w ich aktywności fizycznej (Munster i in. 2015). Istotne jest zwłaszcza konstruowanie instrukcji, jak prowadzić zajęcia wychowania fizycznego dla dzieci niewidomych i słabowidzących w warunkach inkluzji edukacyjnej. Formą popularyzacji aktywności fizycznej są również obozy sportowe dla osób niewidomych i słabowidzących, które ukierunkowane są na naukę umiejętności sportowych i zdobywanie wiedzy dotyczącej dyscyplin oraz bezpieczeństwa (Haegele i in. 2014). Badania ukazują, że mają one istotne znaczenie dla podejmowania spontanicznych aktywności fizycznych w życiu codziennym.

${ }^{4}$ Są to wyniki pracy polskich badaczek, jednak znajdują się one w korpusie tekstów, który jest przedmiotem analiz niniejszego artykułu. 


\section{Refleksje końcowe}

Podejmowane w pracach badawczo-rozwojowych próby opisu i wyjaśnienia zagadnień odnoszących się do funkcjonowania oraz wspierania osób niewidzących i słabowidzących mają charakter głównie idiograficzny. Liczebność badanych grup mieści się na ogół w przedziale 5-30 osób (rzadziej większym), liczne są również studia indywidualnych przypadków. Ma to związek ze względnie małą populacją osób niewidomych i słabowidzących w stosunku do populacji ogólnej oraz do osób z innymi rodzajami niepełnosprawności, ale związane jest także z niehomogenicznością tej grupy (zarówno niewidzących, jak i słabowidzących) - występowaniem licznych czynników różnicujących, co prowokuje raczej do ujawniania złożoności badanych zjawisk, procesów i mechanizmów oraz ich kontekstu niż do prezentowania jednoznacznych tez. Dlatego próby objaśnień nomotetycznych są śladowe. Chociaż stosowane są metody badań ilościowych, to zwykle współwystępują one $z$ analizami jakościowymi. Gdy podmiotem analizy są osoby bez dysfunkcji wzroku - nauczyciele, rehabilitanci i inni specjaliści, grupy badawcze mają od kilkudziesięciu do kilkuset osób, a więc są liczniejsze. W takich przypadkach przeważa stosowanie procedur ilościowych. Do przeprowadzenia badań wykorzystywane są najczęściej sondaże deklaracji (opinii, preferencji), testy osiągnięć oraz arkusze obserwacji, rzadziej procedury eksperymentalne. W ramach strategii badań jakościowych stosuje się wywiady, obserwacje uczestniczące oraz metodę teorii ugruntowanej.

Prowadzone badania mają głównie charakter eksploracyjny, rzadziej weryfikacyjny, chociaż stosuje się także replikacje procedur badawczych w celu potwierdzenia uzyskanych wcześniej danych i wynikających z nich wniosków.

Problematyka prowadzonych badań naukowych i prac rozwojowych uwidacznia koncentrację działaniowo-projektującą (prakseologiczną - nastawienie na skuteczne działanie w obszarze wspierania osób doświadczających dysfunkcji wzroku), oczywiście z uwzględnieniem podejścia obiektywistycznego (empirycznego). Jak zauważa Teresa Hejnicka-Bezwińska: „Oferta skutecznego działania edukacyjnego sytuuje się zawsze w typie racjonalności instrumentalnej, występuje w postaci pedagogii lub pojedynczych dyrektyw. Jest zawsze ofertą skutecznego realizowania celów określonych wartości" (Hejnicka-Bezwińska 2008, s. 251). Istotnie dostarczana wiedza jest czynnikiem inicjującym tworzenie postulatów praktycznych, rekomendacji i instrukcji edukacyjno-rehabilitacyjnych. Jednak przesłanką aksjologiczną dla tych praktyk jest autonomia i podmiotowość jednostki (zarówno jako punkt wyjścia, jak i jako cel), co uwidacznia się w nieustannym dążeniu badaczy do poznawania perspektyw osobowych i jednostkowych znaczeń przypisywanych przez badanych metodom, narzędziom, technikom, doświadczeniom, interakcjom. Dyskurs naukowy w obrębie problematyki niepełnosprawności wzrokowej ma więc charakter głęboko humanistyczny. 


\section{Bibliografia}

Augestad L.B., Jiang L. (2015). Physical activity, physical fitness, and body composition among children and young adults with visual impairments: a systematic review. „British Journal of Visual Impairment”, 3 (33), s. 167-182.

Ball E.M., Nicole C.A. (2015). Changing what it means to be „normal”: a grounded theory study of the mobility choices of people who are blind or have low vision. "Journal of Visual Impairment and Blindness", 4 (109), s. 291-301.

Beal C.R., Rosenblum L.P. (2015). Use of an accessible iPad app and supplemental graphics to build mathematics skills: feasibility study results. „Journal of Visual Impairment and Blindness", 5 (109), s. 383-394.

Browder D., Ahlgrim-Delzell L., Spooner F., Mims P.J., Baker J.N. (2009). Using time delay to teach literacy to students with severe developmental disabilities. „Exceptional Children”, 75, s. 343-364.

Campbell A.F. (2011). Sarah's story: using the Individualized Meaning-centered Approach to Braille Literacy Education (I-M-ABLE). "Journal of Visual Impairment and Blindness", 3 (105), s. 138-141.

Chiu Y.-T., Image of teaching assistants participating in science camps for visual impairments. 14th Biennial Conference International Association of Special Education's (IASE) „New dimensions toward education, advocacy, and collaboration for individuals with special needs”, 21-25 lipca 2015 r., Dolnośląska Szkoła Wyższa, Wrocław.

Cooper J.O., Heron T.E., Heward W.L. (2007). Applied behavior analysis. Wyd. drugie. Upper Saddle River, NJ: Prentice Hall.

D'Andrea M.F. (2012). Preferences and practices among students who read Braille and use assistive technology. „Journal of Visual Impairment and Blindness”, 10 (106), s. 585-596.

D'Aurizio V.R. (2011). I-M-ABLE: a path way to literacy. "Journal of Visual Impairment and Blindness", 3 (105), s. 141-143.

DePountis V.M., Pogrund R.L., Griffin-Shirley N., Lan W.Y. (2015). Technologies used in the study of advanced mathematics by students who are visually impaired in classrooms: teachers' perspectives. „Journal of Visual Impairment and Blindness", 4 (109), s. 265-278.

Farrow K.R. (2015). Using a group approach to motivate adults to learn Braille. "Journal of Visual Impairment and Blindness", 4 (109), s. 318-321.

Giesen J.M., Cavenaugh B.S., McDonnall M.C. (2012). Academic supports, cognitive disability, and mathematics achievement for visually impaired youth: a multilevel modeling approach. „International Journal of Special Education”, 27 (1), s. 17-26.

Graven T. (2015). How blind individuals discriminate Braille characters: an identification and comparison of three discrimination strategies. „British Journal of Visual Impairment”, 2, s. 80-95. 
Haegele J.A. (2015). Promoting leisure-time physical activity for students with visual impairments using generalization tactics. "Journal of Visual Impairment and Blindness", 4 (109), s. 322-326.

Haegele J.A., Lieberman L.J., Lepore M., Lepore-Stevens M. (2014). A service delivery model for physical activity in students with visual impairments: camp abilities. "Journal of Visual Impairment and Blindness", 6 (108), s. 473-483.

Haegele J.A., Porretta D.L. (2015). Validation of a talking pedometer for adolescents with visual impairments in free-living conditions. „Journal of Visual Impairment and Blindness", 3 (109), s. 219-223.

Hejnicka-Bezwińska T. (2008). Pedagogika ogólna. Warszawa: WAiP.

Herzberg T.S., Rosenblum L.P. (2014). Print to Braille: Preparation and accuracy of mathematics materials in K-12 education. „Journal of Visual Impairment and Blindness", 5 (108), s. 355-367.

Holbrook E.A., Caputo J.L., Perry T.L., Fuller D.K., Morgan D.W. (2009). Physical activity, body composition, and perceived quality of life of adults with visual impairment. "Journal of Visual Impairment and Blindness", 1 (103), s. 17-29.

Hooper J.D., Ivy S.E., Hatton D.D. (2014). Using constant time delay to teach braille word recognition. „Journal of Visual Impairment and Blindness”, 2 (108), s. $107-121$.

Ivy S.E., Hatton D.D. (2015). Teaching skill acquisition to individuals with blindness: a systematic review of response prompting procedures. W: Hatton D.D. (red.). International review of research in developmental disabilities: current issues in the education of students with visual impairments, t. 46. Burlington, VT: Elsevier Academic Press.

Ivy S.E., Hooper J.D. (2015). Using constant time delay to teach braille and Nemeth code to students transitioning from print to braille. „Journal of Visual Impairment and Blindness", 5 (109), s. 343-358.

Kim D.S., Emerson R.W. (2014). Effect of cane technique on obstacle detection with the long cane. „Journal of Visual Impairment and Blindness”, 4 (108), s. 335-340.

Koutsoklenis A., Papadopoulos K. (2015). Haptic cues used for outdoor wayfinding by individuals with visual impairments. „Journal of Visual Impairment and Blindness", 1 (108), s. 43-53.

Kriemler S., Meyer U., Martin E., Van Sluijs E.M.F., Andersen L.B., Martin B.W. (2011). Effects of school-based interventions on physical activity and fitness in children and adolescents: a review of reviews and systematic update. „British Journal of Sports Medicine”, 45 (11), s. 923-930.

Kuczyńska-Kwapisz J. (2004). Nowe trendy $w$ tyflopedagogice - prace naukowo-badawcze i publikacje. „Szkoła Specjalna”, nr 1, s. 32-36.

Kuczyńska-Kwapisz J. (red.). (1996). Rehabilitacja niewidomych i słabowidzacych. Tendencje współczesne. Warszawa: CMPP-P MEN. 
Lahav O., Schloerb D.W., Srinivasan M.A. (2015). Orientation and mobility skills and outcome expectations as predictors of employment for young adults with visual impairments. „Journal of Visual Impairment and Blindness", 1 (109), s. 5-16.

Lieberman L.J., MacVicar J.M. (2003). Play and recreational habits of youths who are deaf-blind. „Journal of Visual Impairment and Blindness”, 12 (97), s. 755-768.

Łobacz E. (2004). Światowe tendencje w edukacji i rehabilitacji osób z dysfunkcją wzroku. W: Zabłocki K.J., Gorajewska D. (red.). Pedagogika specjalna - kontynuacja tradycji dla przyszłości. Warszawa: Wydawnictwo APS.

Łobacz E. (2006). Współczesne tendencje w edukacji i rehabilitacji osób niepełnosprawnych wzrokowo. „Szkoła Specjalna”, nr 5, s. 362-372.

McMillan J. (2015). A student success story through the use of an Individualized Meaning-centered Approach to Braille Literacy (I-M-ABLE). „Journal of Visual Impairment and Blindness", 1 (109), s. 56-6o.

Munster M., Weaver E., Lieberman L., Arndt K. (2015). Physical education and visual impairment: collaborative communication for effective inclusion. „Journal of Visual Impairment and Blindness", 3 (109), s. 231-237.

Nepomuceno G.M., Decker D.M., Shaw J.D., Boves L., Tantillo D.J., Wedler H.B. (2016). The value of safety and practicality: recommendations for training disabled students in the sciences with a focus on blind and visually impaired students in chemistry laboratories. "Journal of Chemical Health and Safety”, 23 (1), s. 5-11.

Oshima K., Arai T., Ichihara S., Nakano Y. (2014). Tactile sensitivity and braille reading in people with early blindness and late blindness. „Journal of Visual Impairment and Blindness", 2 (108), s. 122-131.

Reynaga-Peña C. (2015a). A microscopic world at the touch: learning biology with novel $2.5 \mathrm{D}$ and $3 \mathrm{D}$ tactile models. "Journal of Blindness Innovation and Research", nr 1, dostępny na: https://nfb.org/images/nfb/publications/jbir/jbir15/jbiro50103. html (otwarty 15.02.2016).

Reynaga-Peña C. (2015b). Teaching biology to students with visual impairments using three-dimensional tactile auditory models. 14th Biennial Conference International Association of Special Education's (IASE) „New dimensions toward education, advocacy, and collaboration for individuals with special needs", 21-25 lipca 2015 r., Dolnośląska Szkoła Wyższa, Wrocław.

Rosenblum L.P., Herzberg T.S. (2015). Braille and tactile graphics: youths with visual impairments share their experiences. „Journal of Visual Impairment and Blindness", 3 (109), s. 73-184.

Rosołek B., Gawlik K. (2013). Poziom aktywności fizycznej osób z dysfunkcją narządu wzroku a zagrożenia chorobami cywilizacyjnymi - przegląd literatury. „Rozprawy Naukowe Akademii Wychowania Fizycznego we Wrocławiu”, nr 42, s. 103-108.

Sadowska D., Krzepota J. (2015). Assessment of physical activity of people with visual impairments and individuals who are sighted using the international physical activity questionnaire and actigraph. „Journal of Visual Impairment and Blindness", 2 (109), s. 119-129. 
Siu Y.-T., Morash V.S. (2014). Teachers of students with visual impairments and their use of assistive technology: measuring the proficiency of teachers and their identification with a community of practice. „Journal of Visual Impairment and Blindness", 5 (108), s. 384-398.

Smith D.W., Kelley P., Maushak N.J., Griffin-Shirley N., Lan W.Y. (2009). Assistive technology competencies for teachers of students with visual impairments. „Journal of Visual Impairment and Blindness", 8 (103), s. 457-469.

Smith D.L., Penrod W.M. (2010). Adaptive technology for orientation and mobility. W: Wiener W.R., Welsh R.L., Blash B.B. (red.). Foundations of orientation and mobility. Wyd. 3, t. 1. History and Theory. New York: AFB Press.

Śmiechowska-Petrovskij E. (2016). Teaching L. Braille system - new challenges and strategies. W: Krawiecka K., Śmiechowska-Petrovskij E., Tempczyk-Nagórka Ż. (red.). Selected aspects of psychosocial functioning of persons with disabilities. Warszawa: Wydawnictwo UKSW.

Wild T.A., Hilson M.F., Farrand K. (2014). Preparing for an inquiry-based summer camp experience for students with visual impairments: what do the campers think? „Journal of Blindness Innovation and Research”, nr 2, dostępny na: https://nfb. org/images/nfb/publications/jbir/jbir14/jbiro40201.html (otwarty 15.02.2016).

Wormsley D.P. (2011). A theoretical rationale for using the individualized meaning-centered approach to braille literacy education with students who have mild to moderate cognitive disabilities. „Journal of Visual Impairment and Blindness”, 3 (105), s. $145^{-156 .}$

Zebehazy K.T., Wilton A.P. (2014a). Charting success: the experience of teachers of students with visual impairments in promoting student use of graphics. „Journal of Visual Impairment and Blindness", 4 (108), s. 263-274.

Zebehazy K.T., Wilton A.P. (2014b). Quality, importance, and instruction: the perspectives of teachers of students with visual impairments on graphics use by students. "Journal of Visual Impairment and Blindness", 1 (108), s. 5-16.

Zebehazy K.T., Wilton A.P. (2014c). Straight from the source: perceptions of students with visual impairments about graphic use. „Journal of Visual Impairment and Blindness", 4 (108), s. 275-286.

Zhou L., Parker A.T., Smith D.W., Griffen-Shirley N. (2011). Assistive technology for students with visual impairments: challenges and need in teachers' preparation programs and practice. "Journal of Visual Impairment and Blindness”, 4 (105), s. $197-210$.

\section{FIELDS OF RESEARCH IN CONTEMPORARY STUDIES OF VISUALLY IMPAIRMENTS IN OTHER COUNTRIES}

Abstract: The article discusses contemporary directions of research and implementation in the field of functioning, education and rehabilitation of blind and visually impaired 
people. It presents the following main directions: Braille literacy, tactile graphic competences and assistive technologies - strategies in teaching science; contemporary research in orientation and mobility, effectiveness of this process as a predictor of employment; the physical activity of persons with blindness or low vision - data and educational and rehabilitational instructions. The summary of analysis contains methodological and praxeological conclusions.

Key words: blind and visually impaired people, Braille system, orientation and mobility, assistive technology

Emilia Śmiechowska-Petrovskij - doktor nauk społecznych w dyscyplinie pedagogika, pedagog specjalny (tyflopedagog) i filolog polski, adiunkt w Kated rze Pedagogiki Specjalnej, Przedszkolnej i Wczesnoszkolnej Wydziału Nauk Pedagogicznych UKSW, ekspert Ośrodka Rozwoju Edukacji ds. weryfikacji podręczników i książek pomocniczych w brajlu i powiększonym druku. Zainteresowania badawcze: wsparcie osób z niepełnosprawnościami ze szczególnym uwzględnieniem niepełnosprawności wzrokowej, w obszarze edukacji, integracji społecznej i uprzystępniania dóbr kultury. Autorka ponad 20 opracowań naukowych i popularnonaukowych z obszaru tyflopedagogiki. Adres do korespondencji: Wydział Nauk Pedagogicznych, ul. Wóycickiego 1/3, 01-938 Warszawa. Adres e-mail: e.smiechowska@uksw.edu.pl. 